\title{
PERTANIAN
}

\section{PENGARUH KOLKISIN TERHADAP KARAKTER MORFOLOGI TANAMAN TERUNG (Solanum melongena L.)}

\author{
The Effect Colchicine on Morphology of Eggplant (Solanum melongena L.)
}

Dovy Andis Pradana dan Sri Hartatik*

\author{
Program Studi Agroteknologi, Fakultas Pertanian, Universitas Jember \\ Jalan Kalimantan No. 37 Jember, 68121 \\ *E-mail: srihartatik1@yahoo.com
}

\begin{abstract}
The Eggplant (Solanum melongena L.) is one of the plant commodities that has high economic value. Eggplant production is still volatile so plant breeding with a colchicine mutation is needed to increase eggplant production. Colchicine is Colchicum autumnale seed extract which is able to weaken the spindle thread from the metaphase process to anaphase so that chromosome multiplication occurs without the formation of cell walls. Eggplant sprouts induced by different concentrations of colchicine, they are 0 ppm (K0), 100 ppm (K1), 200 ppm (K2) for 6 hours (L1), 12 hours (L2), 18 hours (L3) . The variables observed were morphological characters such as plant height, flowering age, fruit weight, fruit diameter, fruit length, leaf length, leaf width and stem diameter. The results of the treatment show concentration of colchicine and soaking time had a very significant effect on fruit diameter and fruit weight. K1L2 is the most effectif treatment on diameter and weigh of fruit.The concentration of colchicine has a significant effect on plant height and flowering age. The most effectif concentration in plant height and flowering age is $\mathrm{K} 1$.
\end{abstract}

Keywords: Eggplant, Colchicine concentration, Soaking time of colchicine

\begin{abstract}
ABSTRAK
Terung (Solanum melongena L.) merupakan salah satu komoditas tanaman dengan nilai ekonomis tinggi. Produksi terung masih fluktuatif sehingga pemuliaan tanaman dengan mutasi colchicine diperlukan untuk meningkatkan produksi terung. Colchicine merupakan ekstrak dari biji Colchicum autumnale yang mampu melemahkan untaian DNA dari proses metafase menjadi anafase, sehingga multiplikasi kromosom terjadi tanpa pembentukan dinding sel. Kecambah terung diinduksi dengan colchicine dalam konsentrasi yang berbeda, yaitu 0 ppm (K0), 100 ppm (K1), 200 ppm (K2) selama 6 jam (L1), 12 jam (L2), 18 jam (L3). Variabel yang diamati adalah karakter morfologi seperti tinggi tanaman, umur berbunga, berat buah, diameter buah, panjang buah, panjang daun, lebar daun dan diameter batang. Hasil percobaan menunjukkan konsentrasi colchicine dan waktu perendaman memiliki pengaruh yang sangat signifikan terhadap diameter buah dan berat buah. Perlakuan K1L2 merupakan perlakuan yang paling efektif mempengaruhi diameter dan berat buah. Konsentrasi colchicine memiliki efek signifikan terhadap tinggi tanaman dan usia berbunga. Konsentrasi paling efektif terhadap tinggi tanaman dan umur berbunga adalah K1.
\end{abstract}

Kata Kunci: Terung, konsentrasi colchicine, waktu perendaman colchicine

How to citate: Pradana, D. A., dan S. Hartatik. 2019. Pengaruh Kolkisin Terhadap Karakter Morfologi Tanaman Terung (Solanum melongena L.). Berkala Ilmiah Pertanian. 2(4): 155-158.

\section{PENDAHULUAN}

Tanaman terung (Solanum melongena L.) menjadi salah satu komoditas sayuran dengan nilai ekonomi yang cukup tinggi, karena perannya yang besar dalam memenuhi kebutuhan pangan masyarakat Indonesia. Terung merupakan tanaman semusim berbentuk perdu yang tergolong famili Solanaceae. Tanaman ini memiliki banyak kandungan gizi seperti karbohidrat, protein, lemak, zat besi, kalsium, vitamin A, vitamin C, vitamin B1 dan lain sebagainya.

Kebutuhan tanaman terung terus mengalami peningkatan seiring bertambahnya jumlah penduduk (Kementrian Pertanian, 2015). Produksi terung mulai tahun 2009 - 2014 mengalami fluktuasi dimana produksi tertinggi terjadi pada tahun 2014 yaitu 557.040 ton, sedangkan produksi terendah terjadi pada tahun 2009 yaitu 451.564 ton. Rata-rata produksi tanaman terung hanya
10.95 ton/ha. Hal tersebut masih jauh dari potensinya yang dapat mencapai 40 ton/ha. Penyebab tidak maksimalnya produksi terung disebabkan berbagai hal, salah satunya adalah genetik tanaman yang kurang baik (Kementrian Pertanian, 2010).

Upaya yang dapat dilakukan adalah dengan pemuliaan tanaman. Pemuliaan tanaman adalah kegiatan mengubah susunan genetik tanaman yang bertujuan untuk mendapatkan tanaman dengan sifat yang lebih baik. Pemuliaan tanaman terdiri dari pemuliaan tanaman konvensional dan non-konvensional (Soedjono, 1997). Pemuliaan tanaman non-konvensional dibagi menjadi 2 yaitu mutasi dan rekayasa genetika. Mutasi adalah perubahan materi genetik pada makhluk hidup secara tiba-tiba dan bersifat acak. Akibat perubahan materi genetik tersebut menyebabkan efek samping diantaranya karakter morfologi tanaman menjadi abnormal. Pemuliaan tanaman diarahkan untuk memperoleh varietas baru yang resisten terhadap hama dan penyakit penting seperti hawar daun. Secara umum sifat dari tanaman yang 
diharapkan menjadi unggulan Indonesia diantaranya adalah memiliki umur panen yang pendek, berdaya hasil tinggi dan sebagainya (Rahayu dkk., 2015).

Mutasi dapat diterapkan untuk perbaikan sifat genetik tanaman. Mutasi dibagi lagi menjadi mutasi kimia dan fisika. Contoh mutagen (faktor penyebab mutasi) yang biasa digunakan dalam mutasi kimia adalah EMS dan Kolkisin (Wiartana, 2015). Kolkisin berasal dari ekstrak biji Colchicum autumnale yang mampu menginduksi tanaman menjadi tanaman poliploidi pada konsentrasi dan waktu yang tepat. Poliploidi adalah kondisi pada suatu organisme memiliki set kromosom lebih dari sepasang. Kolkisin dengan konsentrasi tertentu akan melemahkan penyusunan mikrotubula benang spindle sehingga mengakibatkan mitosis terhambat.

Peningkatan ploidi akibat kolkisin mempengaruhi morfologi tanaman sepeti meningkatnya ukuran daun, ketebalan daun, tinggi tanaman, jumlah daun, lebar daun dan lain-lain. Perlakuan kolkisin pada tanaman terung harus optimal baik konsentrasi maupun lama perendaman. Konsentrasi dan lama perendaman yang terlalu tinggi atau terlalu rendah tidak dapat mempengaruhi tanaman terung menjadi tanaman poliploid. Menurut Daryono dan Rahmadanti (2009), konsentrasi kolkisin 0,01\% pada tanaman krisan menunjukkan hasil terbaik terhadap diameter batang. Kemudian, Sulistianingsih dkk. (2004) meneliti pengaruh kolkisin terhadap tanaman anggrek Dendrobium hibrida dengan konsentrasi $0,02 \%$ dengan lama perendaman 6 jam menunujukkan hasil terbaik terhadap diameter batang dan ukuran bunga.

Lama perendaman 12 jam menunjukkan hasil terbaik terhadap panjang daun, lebar daun dan umur berbunga pada tanaman stroberi (Aristya dan Daryono, 2014). Sedangkan, Faturrahman (2015) menjelaskan bahwa lama perendaman kolkisin 18 jam pada tanaman kedelai memberikan hasil terbaik pada tinggi tanaman. Penelitian terhadap tanaman terung ini diharapkan mampu memperoleh perlakuan konsentrasi dan lama perendaman kolkisin yang optimal serta memperoleh keragaman genetik potensial yang dapat dikembangkan menjadi varietas baru.

\section{BAHAN DAN METODE}

\section{Alat dan Bahan}

Alat yang digunakan meliputi timbangan, gelas ukur dan pinset sedangkan bahan yang digunakan meliputi kecambah terung, kolkisin dan aquades.

\section{Tahapan Percobaan}

Kecambah terung direndam dalam larutan kolkisin dengan konsentrasi 0 ppm, 100 ppm dan 200 ppm selama 6 jam, 12 jam dan 18 jam. Setelah itu, dilakukan pembibitan, penanaman, perawatan hingga pemanenan

\section{Rancangan Percobaan}

Penelitian ini menggunakan metode Rancangan Acak Lengkap (RAL) 2 faktorial. Faktor pertama terdiri dari 3 taraf dan faktor kedua terdiri dari 3 taraf. Faktor pertama merupakan konsentrasi kolkisin (K) yaitu 0 ppm (K0), 100 ppm (K1) dan 200 ppm (K2) terhadap 100 gram puree buah nanas. Faktor kedua merupakan lama perendaman kolkisin (L) yaitu 6 jam (L1), 12 jam (L2) dan 18 jam (L3). Setiap perlakuan diulang sebanyak 7 kali.

\section{Metode Analisis}

Data yang diperoleh dianalisis dengan uji $\mathrm{F}$ pada taraf kepercayaan $95 \%$. Apabila terdapat perbedaan yang nyata dari nilai tengahnya akan dilanjutkan dengan uji Duncan Multiple Range Test (DMRT). Adapun variabel pengamatan yang digunakan menurut Wiartana (2014) yaitu tinggi tanaman, diameter batang, panjang daun, lebar daun, umur berbunga, diameter buah, panjang buah dan bobot buah.

\section{HASIL DAN PEMBAHASAN}

Berdasarkan hasil pengamatan dan analisis data dapat diketahui bahwa konsentrasi kolkisin dan lama perendaman berpengaruh sangat nyata terhadap diameter buah dan bobot buah. Konsentrasi kolkisin berpengaruh nyata terhadap tinggi tanaman dan umur berbunga. Namun, konsentrasi kolkisin dan lama perendaman tidak berpengaruh nyata terhadap diameter batang, panjang dan lebar daun serta panjang buah.

Data diameter buah dan bobot disajikan pada Tabel 1 . Berdasarkan Tabel 1, interaksi antara konsentrasi dan lama perendaman kolkisin memberikan pengaruh yang sangat nyata terhadap diameter buah dan bobot buah. Pada Tabel 1, diketahui bahwa diameter buah tertinggi adalah 45, $43 \mathrm{~mm}$ (Gambar 1) yang diberi perlakuan kolkisin dengan konsentrasi 100 ppm (K1) dengan lama perendaman 12 jam (L2). Kemudian, untuk perlakuan kolkisin dengan konsentrasi 200 ppm (K2) dan lama perendaman 18 jam (L3) memberikan hasil terendah yaitu 28,80 $\mathrm{mm}$ (Gambar 2). Perlakuan kolkisin dengan konsentrasi 100 ppm (K1) dan lama perendaman selama 12 jam (L2) juga memberikan bobot buah terbaik yaitu 158, 43 g (Gambar 1) sedangkan hasil terendah ditunjukkan oleh konsentrasi $200 \mathrm{ppm}$ (K2) dan lama perendaman 18 jam (L3) yaitu 112,00 gram (Gambar 2).

Kolkisin dengan konsentrasi 100 ppm dan lama perendaman 12 jam merupakan perlakuan optimal terhadap diameter dan bobot buah tanaman terung (Aristya dan Daryono, 2014). Konsentrasi 100 ppm diduga mampu mempengaruhi semua sel pada jaringan buah tanaman terung sehingga mengalami poliploidi. Pada sel yang poliploid, ukuran sel dan inti sel akan bertambah sehingga menghasilkan karakter fenotip yang lebih besar, kekar dan kuat serta bobot yang lebih berat (Syaifudin dkk., 2013).

Tabel 1. Pengaruh Konsentrasi Kolkisin dan Lama Perendaman Terhadap Diameter Buah dan Bobot Buah

\begin{tabular}{|c|c|c|c|c|c|}
\hline No & Variabel & Perlakuan & K0 & K1 & $\mathrm{K} 2$ \\
\hline 1 & Diameter buah & L1 & $36,21 \mathrm{a}$ & $\begin{array}{c}38,34 \mathrm{~b} \\
\mathrm{C}\end{array}$ & $\begin{array}{c}37,34 \mathrm{c} \\
\mathrm{B}\end{array}$ \\
\hline \multirow{5}{*}{2} & \multirow{5}{*}{$\begin{array}{l}\text { Bobot buah } \\
\text { (g) }\end{array}$} & L2 & $\begin{array}{c}36,87 \mathrm{c} \\
\mathrm{B}\end{array}$ & $\begin{array}{c}45,43 \mathrm{c} \\
\mathrm{C}\end{array}$ & $\begin{array}{c}33,43 \mathrm{~b} \\
\mathrm{~A}\end{array}$ \\
\hline & & L3 & $\begin{array}{c}36,47 \mathrm{~b} \\
\mathrm{C}\end{array}$ & $\begin{array}{c}35,54 \mathrm{a} \\
\mathrm{B}\end{array}$ & $\begin{array}{c}28,80 \mathrm{a} \\
\mathrm{A}\end{array}$ \\
\hline & & L1 & $\begin{array}{c}141,14 \mathrm{~b} \\
\mathrm{~A}\end{array}$ & $\begin{array}{c}140,29 \mathrm{~b} \\
\mathrm{~A}\end{array}$ & $\begin{array}{c}146,29 \mathrm{c} \\
\text { B }\end{array}$ \\
\hline & & L2 & $\begin{array}{c}139,71 \mathrm{a} \\
\mathrm{B}\end{array}$ & $\begin{array}{c}158,43 \mathrm{c} \\
\mathrm{C}\end{array}$ & $\begin{array}{c}135,29 \mathrm{~b} \\
\mathrm{~A}\end{array}$ \\
\hline & & L3 & $\begin{array}{c}139,29 \mathrm{a} \\
\mathrm{C}\end{array}$ & $\begin{array}{c}134,00 \mathrm{a} \\
\mathrm{B}\end{array}$ & $\begin{array}{c}112,86 \mathrm{a} \\
\mathrm{A}\end{array}$ \\
\hline
\end{tabular}

Keterangan: Huruf kecil dibaca vertikal dan Huruf kapital dibaca horizontal. Huruf yang berbeda menunjukkan perbedaan yang nyata pada taraf kepercayaan $95 \%$ uji duncan, $\mathrm{K}=$ konsentrasi, $\mathrm{L}=$ Lama perendaman. KK Diameter buah $=21,82 \%$, KK Bobot buah $=19,32 \%$

Hal ini dikarenakan kolkisin berfungsi dalam melemahkan pembentukan bendang spindle yang menyebabkan terhambatnya pemisahan kromosom sehingga kromosom dan duplikatnya tetap dalam satu sel yang sama. Akibatnya, pembelahan tidak berlangsung yang menyababkan terjadinya penambahan kromosom pada sel (Rosmaiti dan Dani, 2015). Selanjutnya, perendaman selama 12 jam diduga merupakan waktu yang paling optimal agar kolkisin mampu mempengaruhi sel-sel pada jaringan buah tanaman terung. 


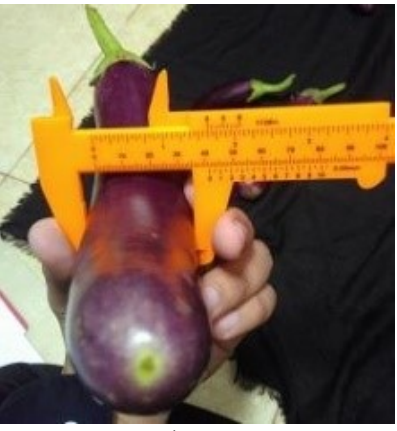

a)

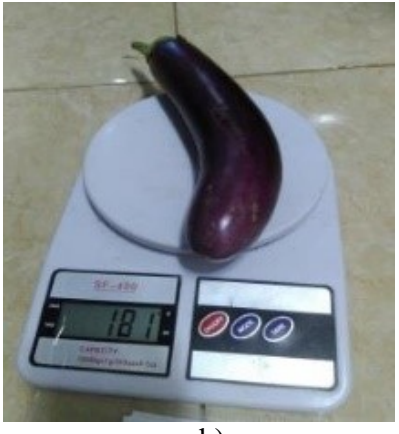

b)
Gambar 1. Perlakuan K1L2 terhadap diameter buah (a) dan bobot buah (b)

Konsentrasi 200 ppm dan lama perendaman 18 jam memberikan hasil terendah terhadap diameter dan bobot buah tanaman terung. Hal ini diduga karena konsentrasi dan lama perendaman tersebut tergolong tinggi dan lama sehingga tidak menghasilkan tanaman dengan sifat poliploidi dan menimbulkan efek negatif seperti penampilan buah yang lebih kecil dan jelek serta kematian tanaman (Sirojuddin dkk., 2017). Selain itu, perlakuan konsentrasi kolkisin dan lama perendaman yang tidak tepat dapat merusak sel pada buah. Rusaknya sel akan menghambat pertumbuhan dan perkembangan buah karena sumber energi yang diperoleh tanaman digunakan untuk proses penyembuhan sel yang rusak tersebut (Sartika dan Basuki, 2017). Pengaruh perlakuan kolkisin pada variabel yang diamati menunujukkan hasil yang beragam. Hal tersebut disebabkan kolkisin merupakan mutagen yang mampu mempengaruhi sel tanaman dan respon tanaman juga berbeda sehingga secara acak menghasilkan karakter yang beragam (Kazi, 2015).

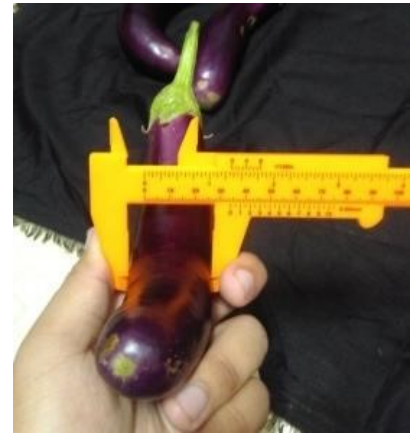

a)

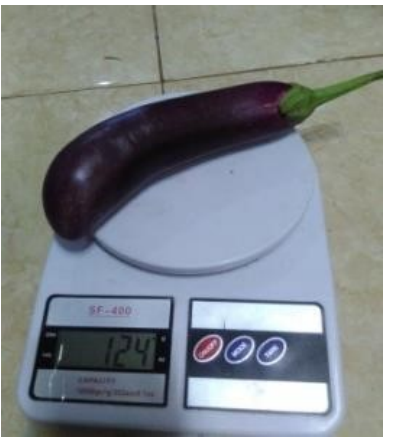

b)
Gambar 2. Perlakuan K2L3 terhadap diameter buah (a) dan bobot buah (b)

Berdasarkan hasil pengamatan dan analisis data dapat diketahui bahwa konsentrasi kolkisin berpengaruh nyata terhadap tinggi tanaman dan umur berbunga. Data tinggi tanaman dan umur berbunga disajikan pada Tabel 2 .

Tabel 2. Pengaruh Konsentrasi Kolkisin Terhadap Tinggi Tanaman dan Umur Berbunga

\begin{tabular}{lcccc}
\hline No & Variabel & K0 & Konsentrasi & K2 \\
& & $79 \mathrm{~b}$ & $81,86 \mathrm{c}$ & $78 \mathrm{a}$ \\
\hline 1 & Tinggi Tanaman (cm) & $33 \mathrm{~b}$ & $32 \mathrm{a}$ & $33 \mathrm{~b}$ \\
2 & Umur Berbunga (Hst) & &
\end{tabular}

Ket : Huruf yang berbeda menunjukkan perbedaan yang nyata pada taraf kepeercayaan $95 \%$ uji duncan. KK Tinggi tanaman = $43 \%$, KK Umur berbunga $=30 \%$

Tabel 2 menunjukkan bahwa konsentrasi kolkisin berpengaruh nyata terhadap tinggi tanaman dan umur berbunga. Tinggi tanaman berdasarkan Tabel 2. menunjukkan bahwa konsentrasi terbaik adalah $100 \mathrm{ppm}(\mathrm{K} 1)$ yaitu $81,86 \mathrm{~cm}$. Menurut Daryono dan Rahmadanti (2009), konsentrasi kolkisin 100 ppm merupakan konsentrasi yang optimal dan memberikan hasil terbaik terhadap tinggi tanaman pada tanaman krisan. Diduga konsentrasi kolkisin $100 \mathrm{ppm}$ merupakan konsentrasi yang optimal juga bagi tinggi tanaman terung. Konsentrasi tersebut mampu merangsang perkembangan sel pada bagian batang tanaman menjadi poliploid. Pada sel yang poliploid, ukuran sel dan inti sel akan bertambah seiring dengan penambahan jumlah kromosom yang menghasilkan tanaman lebih tinggi (Syaifudin dkk., 2013). Selain itu, konsentrasi tersebut tidak menyebabkan kemunduran pada pertumbuhan dan perkembangan tanaman dikarenakan kolkisin bekerja dengan hormon sehingga memacu pertumbuhan tanaman (Sartika dan Basuki, 2017).

Berdasarkan Tabel 2 dapat diketahui bahwa konsentrasi $200 \mathrm{ppm}(\mathrm{K} 2)$ yaitu $78 \mathrm{~cm}$ memberikan hasil tinggi tanaman yang terendah. Konsentrasi 200 ppm diduga merupakan konsentrasi yang tidak tepat sehingga menyebabkan keracunan pada tanaman. Tanaman yang keracunan dapat merusak sel yang akan menghambat pertumbuhan dan perkembangan batang (Sartika dan Basuki, 2017). Sel yang rusak dapat menyebabkan efek negatif seperti penampilan tinggi tanaman yang lebih pendek (Sirojuddin dkk., 2017).

Konsentrasi 100 ppm (K1) memberikan hasil terbaik pada umur berbunga yaitu 32 HST. Menurut (Aristya dan Daryono, 2014), konsentrasi 100 ppm merupakan konsentrasi yang efektif dan mampu mempengaruhi sel-sel pada jaringan tanaman dan menyebabkan pembungaan lebih cepat (Syaifudin dkk.,2013). Pada perlakuan 200 ppm (K2) menunjukkan hasil yang sama dengan 0 ppm (K0) yaitu 33 HST. Konsentrasi tersebut kurang tepat sehingga tidak mampu mempengaruhi tanaman menjadi tanaman poliploidi (Kazi, 2015).

\section{KESIMPULAN}

Konsentrasi kolkisin dan lama perendaman berpengaruh sangat nyata terhadap bobot dan diameter buah terung. Konsentrasi kolkisin dan lama perendaman terbaik pada bobot buah adalah K1L2 (konsentrasi $100 \mathrm{ppm}$ dan lama perendaman 12 jam) yaitu sebesar 158,43 g dan konsentrasi kolkisin dan lama perendaman terbaik pada diameter buah adalah K1L2 (konsentrasi 100 ppm dan lama perendaman 12 jam) yaitu sebesar 45,43 $\mathrm{mm}$.

Konsentrasi kolkisin berpengaruh nyata terhadap tinggi tanaman terung dan umur berbunga. Konsentrasi kolkisin terbaik pada tinggi tanaman adalah K1 $(100 \mathrm{ppm})$ yaitu sebesar $81,86 \mathrm{~cm}$ dan konsentrasi kolkisin terbaik pada umur berbunga adalah K1 (100 ppm) yaitu sebesar 32 HST.

\section{DAFTAR PUSTAKA}

Aristya G. R. dan B. S. Daryono. 2014. Karakter Fenotipik Tanaman Stroberi Festival (Fragaria $\mathrm{x}$ ananassa D.) Hasil Induksi Kolkisin Pada Konsentrasi $0,05 \%$ dan 0,01\%. Biogenesis, 2 (2): 70-78.

Daryono, B. S. dan W. D. Rahmadanti. 2009. Karakter Fenotipe Tanaman Krisan (Dendranthema grandiflorum) Kultivar Big Yellow Hasil Perlakuan Kolkisin. Agrotropika, 14 (1): 15-18.

Faturrahman. 2015. Pemberian Kolkisin Terhadap Pertumbuhan dan Hasil Tanaman Kedelai Hitam (Glycine max (L.) merr). Dinamika Pertanian, 30 (3): 185-190.

Kazi, N. A. 2015. Polyploidy In Solancaceous Crops. AJSM, 3 (4): 69-73.

Kementrian Pertanian. 2015. Statistik Produksi Hortikultura Tahun 2014. Jakarta: Direktorat Jenderal Hortikultura. 
Rahayu, E. M. D., D. Sukma, M. Syukur, S. A. Aziz, dan Irawati. 2015. Induksi Poliploidi Menggunakan Kolkisin Secara In Vivo Pada Bibit Anggrek Bulan (Phalaenopsis amabilis (L.) Blume). Buletin Kebun Raya, 18 (1): 41-48.

Sartika, T. V. dan N. Basuki. 2017. Pengaruh Konsentrasi Kolkisin Terhadap Perakitan Putative Mutan Semangka (Cirullus lanatus). Produksi Tanaman, 5 (10): 1669-1677.

Sirojuddin, T. Rahayu, dan S. Laili. 2017. Pengaruh Pemberian Berbagai Konsentrasi Kolkisin dan Lama Perendaman terhadap Respon Fenotipik Zaitun (Olea europaea). Biosaintropis, 2 (2): 36-41.

Suryo. 1995. Sitogenetika. Yogyakarta: Gadjah Mada University Press.

Syaifudin, A., E. Ratnasari, dan Isnawati. 2013. Pengaruh Pemberian Berbagai Konsentrasi Kolkhisin terhadapPertumbuhan dan Produksi Tanaman Cabai (Capsicum annum) Varietas Lado F1. Lenterabio, 2 (2): 1-5.

Wiartana, I.M.A. 2014. Indusksi Variasi Cabai Merah (Capsicum annum L.) dengan Ethyl Methanesulfonate pada Berbagai Tingkat Waktu Perendaman. Tesis. Fakultas Ilmu Biologi. Universitas Udayana. Denpasar.

Winaryo, K. A. P., A. N. Sugiharto dan Ainurrasjid. 2016. Penampilan Fenotipik 2 Galur Jagung (Zea mays L.) Akibat Pemberian Kolkisin. Produksi Pertanian, 4 (2): 161-168. 